\title{
Fokl polymorphism of the vitamin D receptor (VDR) gene and susceptibility to tuberculosis: evidence through a meta-analysis
}

\author{
Upendra Yadav \\ VBS Purvanchal University, Jaunpur https://orcid.org/0000-0003-2469-8071 \\ Pradeep Kumar \\ VBS Purvanchal University, Jaunpur \\ Vandana Rai ( $\square$ raivandana@rediffmail.com ) \\ VBS Purvanchal University, Jaunpur
}

\section{Systematic Review}

Keywords: VDR, Fokl, tuberculosis, meta-analysis, polymorphism

Posted Date: February 22nd, 2021

DOI: https://doi.org/10.21203/rs.3.rs-266491/v1

License: (c) (i) This work is licensed under a Creative Commons Attribution 4.0 International License.

Read Full License 


\section{Abstract}

Background: Tuberculosis is one of the top ten causes of deaths worldwide. The deficiency of vitamin D was reported to be associated with the increased susceptibility of tuberculosis. Various previous reports were published to check the association of Fokl polymorphism of the vitamin D receptor gene with tuberculosis risk. But their results were inconsistent so, we performed a meta-analysis to know the exact relation of the two.

Methods: Different databases were screened up to November, 2020 with the keywords "Vitamin D receptor", "VDR", and "Fokl", along with "Tuberculosis" and "TB" to find the suitable articles. All the statistical analyses were performed by the Open Meta-Analyst program and all p-values were two-tailed with a significance level of 0.05 .

Results: No statistically significant association was observed in the allele contrast model $\left(\mathrm{OR}_{\mathrm{fvs} . \mathrm{F}}=1.11\right.$, $\left.95 \% \mathrm{Cl}=0.99-1.24, \mathrm{p}=0.05, \mathrm{I}^{2}=73.46 \%\right)$, in the dominant model $\left(\mathrm{OR}_{\mathrm{ff}+\mathrm{Ffvs} . \mathrm{FF}}=1.11,95 \% \mathrm{Cl}=0.96-1.28, \mathrm{p}=\right.$ $\left.0.14, \mathrm{I}^{2}=71.39 \%\right)$, and in the co-dominant model $\left(\mathrm{OR}_{\mathrm{Ffvs} . \mathrm{FF}}=1.05,95 \% \mathrm{Cl}=0.92-1.21, \mathrm{p}=0.41, \mathrm{I}^{2}=65.97 \%\right)$. However, a significant association was found in the homozygote model $\left(\mathrm{OR}_{\mathrm{ffvs} . \mathrm{FF}}=1.32,95 \% \mathrm{Cl}=1.03-\right.$ $\left.1.69, p=0.02, I^{2}=67.02 \%\right)$ and in the recessive model $\left(O R_{F F+F f ~ v s . f f}=1.26,95 \% C l=1.03-1.54, p=0.02, I^{2}=\right.$ $58.01 \%)$. Further analysis was performed on the bases of the ethnicity. In Asian population a significant association was found in the homozygote model $\left(\mathrm{OR}_{\mathrm{ffvs} . \mathrm{FF}}=1.57,95 \% \mathrm{Cl}=1.12-2.21, \mathrm{p}=0.008, \mathrm{I}^{2}=\right.$ $70.37 \%)$ and in the recessive model $\left(\mathrm{OR}_{\mathrm{FF}+\mathrm{Ffvs} . \mathrm{ff}}=1.43,95 \% \mathrm{Cl}=1.08-1.89, \mathrm{p}=0.01, \mathrm{I}^{2}=63.13 \%\right)$.

Conclusion: In conclusion, a significant association of Fokl with tuberculosis susceptibility was found in the overall analysis and in the Asian population.

\section{Background}

Tuberculosis (TB) is an infectious disease caused by the bacterium Mycobacterium tuberculosis. TB is one of the top 10 causes of death globally. In the year 2019 an estimated 10 million people fell ill with TB worldwide and nearly 1.4 million people were died worldwide due to TB [1]. Although, one third of the population of the world is infected with the bacillus but only a tiny percentage of the people may progress to active TB disease [2]. A number of factors are associated with the susceptibility of TB such asenvironmental [3], genetic [4], and HIV infection [5,6] etc. A number of studies were performed to determine the role of single nucleotide polymorphisms (SNPs) in the susceptibility of TB like- natural resistance-associated macrophage protein 1 (NRAMP1) gene [7], interleukin (IL) genes [8,9], vitamin D receptor (VDR) genes [10], and tumor necrosis factor (TNF) genes [11].

Among them the VDR gene is most studied and it has been considered as a risk factor for the TB development process as it may affect the host immunity. The vitamin D receptor interacts with the 1,25dihydroxyvitamin D3 and activates the monocytes, stimulate cell mediated immunity and suppress the proliferation of lymphocytes [12], so the susceptibility to TB may be increased by deficiency of 1,25- 
dihydroxyvitamin D3. The VDR gene is located on chromosome 12 that spans approximately $75 \mathrm{~kb}$ of genomic DNA and contains 11 exons [13]. One of the most studied polymorphism of the VDR gene is Fokl. A polymorphic variant (FF) is generated from a change of $\mathrm{T}$ to $\mathrm{C}$ in the start codon sequence that is shortened by three amino acids and shows increased transcriptional efficiency of the VDR protein as compared to the long ff allele form [14].

Several studies were performed to check the association of Fokl polymorphism with the susceptibility of TB. The results of these studies were inconclusive so we designed this study to determine the role of FokI in the TB susceptibility.

\section{Materials And Methods}

\section{Study selection}

The studies for the present meta-analysis were searched through four databases viz. PubMed, Google scholar, SpringerLink and Elsevier. These databases were searched with the keywords "Vitamin D receptor", "VDR", and "Fokl", along with "Tuberculosis" and "TB". The articles were selected up to November, 2020.

\section{Inclusion and exclusion criteria}

We included the studies if they met following criteria-i) case-control study; ii) provided data of alleles and genotypes for the case and control groups. At the same time, we excluded those studies which were i) reported case only; ii) performed on the animal models; iii) other than English language; iv) review and meta-analyses.

\section{Data extraction}

From all the selected articles the authors extracted following information-i) first author's last name; ii) year of publication; iii) ethnicity; iv) number of alleles and/or genotypes. All these information's were retrieved by the authors independently and if any inconsistency was found it was resolved by the mutual discussion.

\section{Meta-analysis}

For the present study, we constructed five genetic models through the data extracted from different included studies. The five genetic models are allele contrast, dominant, homozygote, co-dominant and recessive. We calculated odds ratio (OR) and $95 \%$ confidence interval $(\mathrm{Cl})$ for all the individual studies 
and then pooled OR and $95 \% \mathrm{Cl}$ was calculated by the method of Mantel and Haenszel [15] for the fixed effect model and by the method of DerSimonian and Laird [16] for the random effect model. The choice of the best fit model was determined by the between study heterogeneity, which was calculated by the Qstatistics (a p-value of less than 0.05 was considered as statistically significant) and $\mathrm{I}^{2}$ statistics was used to quantify the inconsistency of between study estimates. Sub-group analysis based on ethnicity was also performed. Potential publication bias was identified by the evaluation of the funnel plot. The linear regression method of Egger et al. [17] was used for further evaluation of the publication bias. All the statistical analyses were performed in the Open Meta-Analyst program [18]. All p-values were twotailed with a significance level of 0.05 .

\section{Results}

\section{Eligible studies}

With our search criteria we identified 1098 articles from different databases. After application of our study selection criteria we identified a total of 44 articles suitable for inclusion in the present metaanalysis [10, 19-61]. Out of 44 studies, 29 studies were belong to Asia, eight studies were from Africa, one from Europe and 6 studies were from South America.

\section{Meta-analysis}

In the overall analysis the heterogeneity was very high and no statistically significant association was observed in the allele contrast model $\left(\mathrm{OR}_{\mathrm{fvs} . \mathrm{F}}=1.11,95 \% \mathrm{Cl}=0.99-1.24, \mathrm{p}=0.05, \mathrm{I}^{2}=73.46 \%\right)$ (Fig. 1$)$. Similar results were found in the dominant model $\left(\mathrm{OR}_{\mathrm{ff}+\mathrm{Ffvs} . \mathrm{FF}}=1.11,95 \% \mathrm{Cl}=0.96-1.28, \mathrm{p}=0.14, \mathrm{I}^{2}=\right.$ $71.39 \%)$ (Fig. 2) and co-dominant model $\left(\mathrm{OR}_{\mathrm{Ffvs} . \mathrm{FF}}=1.05,95 \% \mathrm{Cl}=0.92-1.21, \mathrm{p}=0.41, \mathrm{I}^{2}=65.97 \%\right) . \mathrm{A}$ significant association was found in the homozygote model $\left(\mathrm{OR}_{\mathrm{ffvs} . \mathrm{FF}}=1.32,95 \% \mathrm{Cl}=1.03-1.69, \mathrm{p}=0.02\right.$, $\left.\mathrm{I}^{2}=67.02 \%\right)(\mathrm{Fig} .3)$ and in the recessive model $\left(\mathrm{OR}_{\mathrm{FF}+\mathrm{Ff} \mathrm{vs.ff}}=1.26,95 \% \mathrm{Cl}=1.03-1.54, \mathrm{p}=0.02, \mathrm{I}^{2}=58.01 \%\right)$ (Fig. 4). High heterogeneity was found in all the genetic models so the random effect model was applied (Table 1).

Further analysis was performed on the bases of the ethnicity. In Asian population high heterogeneity was found in all the genetic models so the random effect model was applied. No significant association was found in the allele contrast model $\left(\mathrm{OR}_{\mathrm{fvs} . \mathrm{F}}=1.15,95 \% \mathrm{Cl}=0.98-1.34, \mathrm{p}=0.06, \mathrm{I}^{2}=77.48 \%\right)$, dominant model $\left(\mathrm{OR}_{\mathrm{ff}+\mathrm{Ffvs} . \mathrm{FF}}=1.15,95 \% \mathrm{Cl}=0.93-1.41, \mathrm{p}=0.18, \mathrm{I}^{2}=77.47 \%\right)$ and co-dominant model $\left(\mathrm{OR}_{\mathrm{Ffvs} . \mathrm{FF}}=1.06\right.$, $\left.95 \% \mathrm{Cl}=0.86-1.31, \mathrm{p}=0.53, \mathrm{I}^{2}=74.73 \%\right)$. However, a significant association was found in the homozygote model $\left(\mathrm{OR}_{\mathrm{ffvs} . \mathrm{FF}}=1.57,95 \% \mathrm{Cl}=1.12-2.21, \mathrm{p}=0.008, \mathrm{I}^{2}=70.37 \%\right)$ and in the recessive model $\left(\mathrm{OR} \mathrm{FF}_{\mathrm{Ff} \text { vs.ff }}=\right.$ $\left.1.43,95 \% \mathrm{Cl}=1.08-1.89, \mathrm{p}=0.01, \mathrm{I}^{2}=63.13 \%\right)($ Table 1$)$. 
Furthermore, no association was found in any genetic models in the African and South American populations. In the African studies no heterogeneity was observed but in the South American studies high between study heterogeneity was found (Table 1 ).

\section{Sensitivity analysis}

The sensitivity analysis was performed by the exclusion of the studies that were deviated from the HardyWeinberg equilibrium (HWE). Total seven studies [30, 32, 34, 51, 52, 54, 61] were deviated from the HWE. After removal of these studies we again performed the overall meta-analysis and sub-group metaanalysis. The overall heterogeneity was increased while the odds ratio marginally increased $\left(\mathrm{OR}_{\mathrm{ffv}} \mathrm{FF}=\right.$ $\left.1.34 ; 95 \% \mathrm{Cl}=1.03-1.73 ; p=0.02, \mathrm{I}^{2}=69.22 \%\right)$.

\section{Publication bias}

The symmetry in the funnel plots showed absence of publication bias (Fig. 5). The p-value of Egger's test were more than 0.05 in all models which showed no publication bias statistically (Table 1 ).

\section{Discussion}

The present study was designed to evaluate the role of the Fokl polymorphism in the etiology of the TB because a number of studies were published before with inconclusive results. In this study we found that the homozygote model $\left(\mathrm{OR}_{\mathrm{ffvs} . \mathrm{FF}}=1.32,95 \% \mathrm{Cl}=1.03-1.69, \mathrm{p}=0.02, \mathrm{I}^{2}=67.02 \%\right)$ and recessive model $\left(O R_{F F+F f v s . f f}=1.26,95 \% \mathrm{Cl}=1.03-1.54, p=0.02, I^{2}=58.01 \%\right)$ of the overall studies was significantly associated with the TB. Again, we performed the sub-group analysis on the basis of the ethnicity and found that the Asian population is at risk of developing TB in the homozygote model $\left(\mathrm{OR}_{\mathrm{ffvs} . \mathrm{FF}}=1.57\right.$, $\left.95 \% \mathrm{Cl}=1.12-2.21, \mathrm{p}=0.008, \mathrm{I}^{2}=70.37 \%\right)$ and recessive model $\left(\mathrm{OR}_{\mathrm{FF}+\mathrm{Ffv} . \mathrm{ff}}=1.43,95 \% \mathrm{Cl}=1.08-1.89, \mathrm{p}=\right.$ $\left.0.01, \mathrm{I}^{2}=63.13 \%\right)$.

The susceptibility of developing TB in different populations is different that may be due to the genetic variations among the populations. In the various previous studies, a number of gene polymorphisms have been found to be associated with the TB risk. One such gene polymorphism is Fokl of the VDR gene. Vitamin D suppresses the proliferation of lymphocytes and activates monocytes. It also suppresses the cytokine synthesis and production of immunoglobulins; thus, it plays a crucial role in human innate immunity to the infectious agents including M. tuberculosis [62]. How vitamin D suppresses the infection of $M$. tuberculosis is not clear but one of the suggested mechanism is the production of cathelicidin. Vitamin $D$ induces the production of cathelicidin, an antimicrobial peptide, which restricts the growth of M. tuberculosis in the macrophages [63] so it provides defense against the development of TB. The macrophages convert circulating $25(\mathrm{OH})$ vitamin $\mathrm{D}$ to $1,25(\mathrm{OH})$ vitamin $\mathrm{D}$ during bacterial infection, 
which stimulates the expression of the genes encoding the antimicrobial peptides like cathelicidin [64]. This peptide is secreted by peripheral immune cells and respiratory epithelial cells [65]. Cathelicidin is a molecule that is essential for normal immune responses to infection. It has many properties like- cytokine release, tissue regeneration and also inhibits apoptosis of neutrophil [66].

Meta-analysis is a powerful tool in evaluating the risk of a disease with a particular gene. It combines the low powered studies to make a pooled study with more statistical power. In recent years by using this technique a number of studies were published which clarifies the relationship between a gene polymorphisms and some disease/or disorder like- Down syndrome [67, 68], glucose-6-phosphate dehydrogenase deficiency [69] neural tube defects [70], male infertility [71], osteoporosis [72], cancer [7378] etc.

So far nine meta-analyses were published, which evaluated the role of VDR Fokl gene polymorphism in the etiology of the TB [79-87]. In few meta-analyses no significant association was found in between the Fokl polymorphism and TB $[79,86,87]$. In a study conducted by Gao et al. [80] a significant association in the homozygote model $\left(\mathrm{OR}_{\mathrm{ffvs} . \mathrm{FF}}=1.5,95 \% \mathrm{Cl}=1.1-2.0, \mathrm{p}=<0.1\right)$ was found. Chen et al. [81] found association in the recessive model $(\mathrm{OR}=1.36,95 \% \mathrm{Cl}=1.14-1.62, \mathrm{p}=0.002)$ only. Low heterogeneity was found in the study of Sun and Cai [82] and they found significant association $\left(\mathrm{OR}_{\mathrm{ffvs} . \mathrm{FF}}=1.36,95 \% \mathrm{Cl}=\right.$ 1.11-1.66). Similar results with low heterogeneity was found in the study of Huang et al. [83] (OR $\mathrm{ffvs}_{\mathrm{FF}+\mathrm{fF}}=$ $1.34,95 \% \mathrm{Cl}=1.09-1.64, \mathrm{p}=0.005)$. Significant association was also reported in the studies of Cao et al. [84] $\left(\mathrm{OR}_{\mathrm{ffvs} . \mathrm{FF}}=1.37,95 \% \mathrm{Cl}=1.17-1.60\right)$ and Wang and $\mathrm{Li}[85]\left(\mathrm{OR}_{\mathrm{FF}+\mathrm{Ffvs} . \mathrm{ff}}=1.30,95 \% \mathrm{Cl}=1.06-1.59, \mathrm{p}=\right.$ $0.01)$.

There are few limitations in our meta-analysis which we want to acknowledge here- First, in our metaanalysis we included only those studies which were published in English, which might introduce potential bias. Second, based on our calculations we found a significant deviation from the HWE in the control population for seven studies. So, we performed sensitivity analysis after exclusion of these studies but no significant improvement in the results were found. Third, in some sub-groups only a few studies were present for sub-group analyses which might not represent the entire population so more studies are needed to confirm the association of Fokl polymorphisms and risk of TB.

\section{Conclusions}

VDR Fokl gene polymorphism is found to be associated with the increased susceptibility to the TB in overall the analysis. While no such association was found in the sub-group analyses.

\section{Declarations}

Declaration of conflict of interest: All the authors declare that there is no conflict of interest. 
Acknowledgements: Upendra Yadav is highly thankful to the VBS Purvanchal University, Jaunpur for providing him financial assistance in the form of VBS Purvanchal University postdoctoral fellowship (VBSPU-PDF).

\section{References}

1. WHO (2020) Global tuberculosis report 2020. Geneva: World Health Organization; 2020.

2. Delgado JC, Baena A, Thim S, Goldfeld AE (2002) Ethnic-specific genetic associations with pulmonary tuberculosis. J Infect Dis 186: 1463-8.

3. Hillerdal G (2000) Environmental dangers: asbestos and tuberculosis. Respiration 67: 134.

4. Newport MJ, Nejentsev S (2004) Genetics of susceptibility to tuberculosis in humans. Monaldi Arch Chest Dis 61: 102-11.

5. Bowen EF, Rice PS, Cooke NT, Whitfield RJ, Rayner CF (2000) HIV seroprevalence by anonymous testing in patients with Mycobacterium tuberculosis and in tuberculosis contacts. Lancet 356:14889.

6. Raghavan S, Alagarasu K, Selvaraj P (2012) Immunogenetics of HIV and HIV associated tuberculosis. Tuberculosis (Edinb). 92:18-30.

7. Borgdorff MW (1998) The NRAMP1 gene and susceptibility to tuberculosis. N Engl J Med 339: 199200.

8. Diagbouga S, Aldebert D, Fumoux F, Capron M, Ledru E (1999) Relationship between interleukin-5 production and variations in eosinophil counts during HIV infection in West Africa: influence of Mycobacterium tuberculosis infection. Scand J Immunol 49: 203-9.

9. Wilkinson RJ, Patel P, Llewelyn M, Hirsch CS, Pasvol G, et al. (1999) Influence of polymorphism in the genes for the interleukin (IL)-1 receptor antagonist and IL-1beta on tuberculosis. J Exp Med 189: 1863-74.

10. Selvaraj P, Kurian SM, Chandra G, Reetha AM, Charles N, Narayanan PR. (2004) Vitamin D receptor gene variants of Bsml, Apal, Taql, and Fokl polymorphisms in spinal tuberculosis. Clin Genet. 65(1):73-6.

11. Selvaraj P, Sriram U, Mathan KS, Reetha AM, Narayanan PR (2001) Tumour necrosis factor alpha (-238 and -308) and beta gene polymorphisms in pulmonary tuberculosis: haplotype analysis with HLA-A, B and DR genes. Tuberculosis (Edinb). 81: 335-41.

12. Tachi Y, Shimpuku H, Nosaka Y, Kawamura T, Shinohara M, et al. (2003) Vitamin D receptor gene polymorphism is associated with chronic periodontitis. Life Sci 73: 3313-21.

13. Taymans SE, Pack S, Pak E, Orban Z, et al. Huang J Bone Miner Res. 14:1163-6.

14. Uitterlinden AG, Fang Y, Van Meurs JB, Pols HA, et al. (2004) Genetics and biology of vitamin D receptor polymorphisms. Gene 338:143-56.

15. Mantel N, Haenszel W (1959) Statistical aspects of the analysis of data from retrospective studies of disease. J Natl Cancer Inst. 22(4):719-48. 
16. DerSimonian R, Laird N (1986) Meta-analysis in clinical trials. Control Clin Trials. 7:177-88.

17. Egger M, Smith DJ, Schneider M, Minder C (1997) Bias in meta-analysis detected by a simple, graphical test. BMJ. 315(7109):629-34.

18. Wallace BC, Dahabreh IJ, Trikalinos TA, Lau J, Trow P, Schmid CH (2013) Closing the gap between methodologists and end-users: R as a computational back-end. J Stat Software. 49, 1-15.

19. Wilkinson RJ, Llewelyn M, Toossi Z, Patel P, Pasvol G, Lalvani A, et al. (2000) Influence of vitamin D deficiency and vitamin $D$ receptor polymorphisms on tuberculosis among Gujarati Asians in west London: a case-control study. Lancet 355(9204):618-21.

20. Selvaraj P, Chandra G, Kurian SM, Reetha AM, Narayanan PR (2003) Association of vitamin D receptor gene variants of Bsml and Fokl polymorphisms with susceptibility or resistance to pulmonary tuberculosis. Curr Sci. 84(12):1564-8.

21. Bornman L, Campbell SJ, Fielding K, Bah B, Sillah J, Gustafson P, et al. (2004) Vitamin D receptor polymorphisms and susceptibility to tuberculosis in West Africa: a case-control and family study. J Infect Dis 190(9):1631-41.

22. Liu W, Cao WC, Zhang CY, Tian L, Wu XM, Habbema JD, et al. (2004) VDR and NRAMP1 gene polymorphisms in susceptibility to pulmonary tuberculosis among the Chinese Han population: a case-control study. Int J Tuberc Lung Dis. 8(4):428-34.

23. Roth DE, Soto G, Arenas F, Bautista CT, Ortiz J, Rodriguez R, et al. (2004) Association between vitamin $\mathrm{D}$ receptor gene polymorphisms and response to treatment of pulmonary tuberculosis. $J$ Infect Dis. 190(5):920-7.

24. Selvaraj P, Chandra G, Jawahar MS, Rani MV, Rajeshwari DN, Narayanan PR (2004) Regulatory role of vitamin D receptor gene variants of Bsm I, Apa I, Taq I, and Fok I polymorphisms on macrophage phagocytosis and lymphoproliferative response to mycobacterium tuberculosis antigen in pulmonary tuberculosis. J Clin Immunol 24(5):523-32.

25. Lombard Z, Dalton DL, Venter PA, Williams RC, Bornman L (2006) Association of HLA-DR, -DQ, and vitamin $D$ receptor alleles and haplotypes with tuberculosis in the Venda of South Africa. Hum Immunol 67(8):643-54.

26. Babb C, van der Merwe L, Beyers N, Pheiffer C, Walzl G, Duncan K, et al. (2007) Vitamin D receptor gene polymorphisms and sputum conversion time in pulmonary tuberculosis patients. Tuberculosis (Edinb). 87(4):295-302.

27. Olesen R, Wejse C, Velez DR, Bisseye C, Sodemann M, Aaby P, et al. (2007) DC-SIGN (CD209), pentraxin 3 and vitamin $D$ receptor gene variants associate with pulmonary tuberculosis risk in West Africans. Genes Immun. 8(6):456-67.

28. Søborg C, Andersen AB, Range N, Malenganisho W, Friis H, Magnussen P, et al. (2007) Influence of candidate susceptibility genes on tuberculosis in a high endemic region. Mol Immunol. 44(9):221320.

29. Wilbur AK, Kubatko LS, Hurtado AM, Hill KR, Stone AC (2007) Vitamin D receptor gene polymorphisms and susceptibility M. tuberculosis in native Paraguayans. Tuberculosis (Edinb). 
87(4):329-37.

30. Selvaraj P, Vidyarani M, Alagarasu K, Prabhu Anand S, Narayanan PR (2008) Regulatory role of promoter and 3' UTR variants of vitamin D receptor gene on cytokine response in pulmonary tuberculosis. J Clin Immunol. 28(4):306-13.

31. Alagarasu K, Selvaraj P, Swaminathan S, Narendran G, Narayanan PR (2009) 5' regulatory and 3' untranslated region polymorphisms of vitamin $D$ receptor gene in south Indian HIV and HIV-TB patients. J Clin Immunol. 29(2):196-204.

32. Merza M, Farnia P, Anoosheh S, Varahram M, Kazampour M, Pajand O, et al. (2009) The NRAMPI, VDR and TNF-alpha gene polymorphisms in Iranian tuberculosis patients: the study on host susceptibility. Braz J Infect Dis. 13(4):252-6.

33. Selvaraj P, Prabhu Anand S, Harishankar M, Alagarasu K (2009) Plasma 1,25 dihydroxy vitamin D3 level and expression of vitamin $\mathrm{d}$ receptor and cathelicidin in pulmonary tuberculosis. $\mathrm{J}$ Clin Immunol. 29(4):470-8.

34. Vidyarani M, Selvaraj P, Raghavan S, Narayanan PR (2009) Regulatory role of 1, 25-dihydroxyvitamin D3 and vitamin D receptor gene variants on intracellular granzyme A expression in pulmonary tuberculosis. Exp Mol Pathol. 86(1):69-73.

35. Banoei MM, Mirsaeidi MS, Houshmand M, Tabarsi P, Ebrahimi G, Zargari L, et al. (2010) Vitamin D receptor homozygote mutant $\mathrm{tt}$ and $\mathrm{bb}$ are associated with susceptibility to pulmonary tuberculosis in the Iranian population. Int J Infect Dis. 14(1):e84-5.

36. Marashian SM, Farnia P, Seyf S, Anoosheh S, Velayati AA (2010) Evaluating the role of vitamin D receptor polymorphisms on susceptibility to tuberculosis among Iranian patients: a case-control study. Tuberk Toraks. 58(2):147-53.

37. Zhang HQ, Deng A, Guo CF, Wang YX, Chen LQ, Wang YF, et al. (2010) Association between Fokl polymorphism in vitamin $D$ receptor gene and susceptibility to spinal tuberculosis in Chinese Han population. Arch Med Res. 41(1):46-9.

38. Ates O, Dolek B, Dalyan L, Musellim B, Ongen G, Topal-Sarikaya A (2011) The association between Bsml variant of vitamin D receptor gene and susceptibility to tuberculosis. Mol Biol Rep. 38(4):26336.

39. Kang TJ, Jin SH, Yeum CE, Lee SB, Kim CH, Lee SH, et al. (2011) Vitamin D Receptor Gene Taql, Bsml and Fokl Polymorphisms in Korean Patients with Tuberculosis. Immune Netw. 11(5):253-7.

40. Sharma PR, Singh S, Jena M, Mishra G, Prakash R, Das PK, et al. (2011) Coding and non-coding polymorphisms in VDR gene and susceptibility to pulmonary tuberculosis in tribes, castes and Muslims of Central India. Infect Genet Evol. 11(6):1456-61.

41. Singh A, Gaughan JP, Kashyap VK (2011) SLC11A1 and VDR gene variants and susceptibility to tuberculosis and disease progression in East India. Int J Tuberc Lung Dis. 15(11):1468-74,

42. Rathored J, Sharma SK, Singh B, Banavaliker JN, Sreenivas V, Srivastava AK, et al. (2012) Risk and outcome of multidrug-resistant tuberculosis: vitamin $D$ receptor polymorphisms and serum $25(\mathrm{OH})$ D. Int J Tuberc Lung Dis. 16(11):1522-8. 
43. Arji N, Busson M, Iraqi G, Bourkadi JE, Benjouad A, Bouayad A, et al. (2014) Genetic diversity of TLR2, TLR4, and VDR loci and pulmonary tuberculosis in Moroccan patients. J Infect Dev Ctries. 8(4):43040.

44. Joshi L, Ponnana M, Penmetsa SR, Nallari P, Valluri V, Gaddam S (2014) Serum vitamin D levels and VDR polymorphisms (Bsml and Fokl) in patients and their household contacts susceptible to tuberculosis. Scand J Immunol. 79(2):113-9.

45. Mahmoud AA, Ali AHK (2014) Vitamin D receptor gene polymorphism and 25 hydroxy vitamin D levels in Egyptian patients with pulmonary tuberculosis. Egypt $\mathrm{J}$ Chest Dis Tuberc. 63:651-5.

46. Rashedi J, Asgharzadeh M, Moaddab SR, Sahebi L, Khalili M, Mazani M, et al. (2014) Vitamin D receptor gene polymorphism and vitamin D plasma concentration: correlation with susceptibility to tuberculosis. Adv Pharm Bull. 4(Suppl 2):607-11.

47. Sinaga BY, Amin M, Siregar Y, Sarumpaet SM. (2014) Correlation between Vitamin D receptor gene Fokl and Bsml polymorphisms and the susceptibility to pulmonary tuberculosis in an Indonesian Batak-ethnic population. Acta Med Indones. 46(4):275-82.

48. Fernández-Mestre M, Villasmil Á, Takiff H, Alcalá ZF (2015) NRAMP1 and VDR Gene Polymorphisms in Susceptibility to Tuberculosis in Venezuelan Population. Dis Markers. 2015:860628.

49. Salimi S, Farajian-Mashhadi F, Alavi-Naini R, Talebian G, Narooie-Nejad M. (2015) Association between vitamin $D$ receptor polymorphisms and haplotypes with pulmonary tuberculosis. Biomed Rep. 3(2):189-94.

50. Wu L, Deng H, Zheng Y, Mansjö M, Zheng X, Hu Y, et al. (2015) An association study of NRAMP1, VDR, MBL and their interaction with the susceptibility to tuberculosis in a Chinese population. Int $J$ Infect Dis. 38:129-35.

51. Acen EL, Worodria W, Mulamba P, Kambugu A, Erume J (2016) The frequency distribution of vitamin D Receptor fok I gene polymorphism among Ugandan pulmonary TB patients. F1000Res. 5:ISCB Comm J-1890.

52. Jafari M, Nasiri MR, Sanaei R, Anoosheh S, Farnia P, Sepanjnia A, et al. (2016) The NRAMP1, VDR, TNF-alpha, ICAM1, TLR2 and TLR4 gene polymorphisms in Iranian patients with pulmonary tuberculosis: A case-control study. Infect Genet Evol. 39:92-8.

53. Lee SW, Chuang TY, Huang HH, Liu CW, Kao YH, Wu LS (2016) VDR and VDBP genes polymorphisms associated with susceptibility to tuberculosis in a Han Taiwanese population. J Microbiol Immunol Infect. 49(5):783-7.

54. Medapati RV, Suvvari S, Godi S, Gangisetti P (2017) NRAMP1 and VDR gene polymorphisms in susceptibility to pulmonary tuberculosis among Andhra Pradesh population in India: a case-control study. BMC Pulm Med. 17(1):89.

55. Wang G, Xie L, Hu J, Lu H, Liu X, Cao Y, et al. (2017) Osteopontin, Bone Morphogenetic Protein-4, and Vitamin D Receptor Gene Polymorphisms in the Susceptibility and Clinical Severity of Spinal Tuberculosis. Cell Physiol Biochem. 41(5):1881-93. 
56. Devi KR, Mukherjee K, Chelleng PK, Kalita S, Das U, Narain K (2018) Association of VDR gene polymorphisms and 22 bp deletions in the promoter region of TLR2delta22 (-196-174) with increased risk of pulmonary tuberculosis: A case-control study in tea garden communities of Assam. J Clin Lab Anal. 32(7):e22562.

57. Zhang Y, Zhu H, Yang X, Guo S, Liang Q, Lu Y, et al. (2018) Serum vitamin D level and vitamin D receptor genotypes may be associated with tuberculosis clinical characteristics: A case-control study. Medicine (Baltimore). 97(30):e11732.

58. Panda S, Tiwari A, Luthra K, Sharma SK, Singh A (2019) Association of Fok1 VDR polymorphism with Vitamin $D$ and its associated molecules in pulmonary tuberculosis patients and their household contacts. Sci Rep. 9(1):15251.

59. Silva-Ramírez B, Saenz-Saenz CA, Bracho-Vela LA, Peñuelas-Urquides K, Mata-Tijerina V, EscobedoGuajardo BL, et al. (2019) Association between vitamin D receptor gene polymorphisms and pulmonary tuberculosis in a Mexican population. Indian J Tuberc. 66(1):70-5.

60. Silva CA, Fernandes DCRO, Braga ACO, Cavalcante GC, Sortica VA, Hutz MH, et al. (2020) Investigation of genetic susceptibility to Mycobacterium tuberculosis (VDR and IL10 genes) in a population with a high level of substructure in the Brazilian Amazon region. Int $\mathrm{J}$ Infect Dis. 98:44753.

61. de Albuquerque Borborema ME, de Souza Pereira JJ, Dos Santos Peixoto A, Crovella S, Schindler HC, da Silva Rabello MC, et al. (2020) Differential distribution in vitamin D receptor gene variants and expression profile in Northeast Brazil influences upon active pulmonary tuberculosis. Mol Biol Rep. 47(9):7317-22.

62. Haussler MR, Whitfield GK, Haussler CA, Hsieh JC, Thompson PD, Selznick SH et al. (1998) The nuclear vitamin $\mathrm{D}$ receptor: biological and molecular regulatory properties revealed. J Bone Miner Res. 13, 325-349.

63. Liu PT, Stenger S, Li H, Wenzel L, Tan BH, Krutzik SR et al. (2006) Toll-like receptor triggering of a vitamin D-mediated human antimicrobial response. Science 311, 1770-3.

64. White JH (2010) Vitamin D as an inducer of cathelicidin antimicrobial peptide expression: past, present and future. J Steroid Biochem Mol Biol 121:234-8.

65. Iqbal SF, Freishtat RJ (2011) The mechanism of action of Vitamin D in the asthmatic lung. J Investig Med 59(8):1200-2.

66. Yeung AT, Gellatly SL, Hancock RE (2011) Multifunctional cationic host defence peptides and their clinical applications. Cell Mol Life Sci. 68:2161-76.

67. Rai V, Yadav U, Kumar P, Yadav SK, Mishra OP (2014) Maternal methylenetetrahydrofolate reductase C677T polymorphism and down syndrome risk: a meta-analysis from 34 studies. PLoS One. 9(9):e108552.

68. Rai V, Kumar P (2018) Fetal MTHFR C677T polymorphism confers no susceptibility to Down Syndrome: evidence from meta-analysis. Egypt J Med Hum Genet. 19:53-58. 
69. Kumar P, Yadav U, Rai V (2016) Prevalence of Glucose-6-phosphate dehydrogenase deficiency in India: an updated meta-analysis. Egypt J Med Hum Genet 17: 295-302.

70. Yadav U, Kumar P, Yadav SK, Mishra OP, Rai V (2015) "Polymorphisms in folate metabolism genes as maternal risk factor for neural tube defects: an updated meta-analysis". Metab Brain Dis. 30(1):7-24.

71. Rai V, Kumar P (2017) Methylenetetrahydrofolate Reductase C677T Polymorphism and Risk for Male Infertility in Asian Population. Indian J Clin Biochem. 32(3):253-260.

72. Yadav U, Kumar P, Rai V (2020) Vitamin D receptor (VDR) gene Fokl, Bsml, Apal and Taql polymorphisms and osteoporosis risk: a meta-analysis. Egypt J Med Hum Genet (In press) doi.org/10.1186/s43042-020-00057-5.

73. Rai V (2014) The methylenetetrahydrofolate reductase C677T polymorphism and breast cancer risk in Asian populations. Asian Pac J Cancer Prev. 15(14): 5853-60.

74. Kumar P, Yadav U, Rai V (2015) Methylenetetrahydrofolate reductase gene C677T polymorphism and breast cancer risk: Evidence for genetic susceptibility. Meta Gene 6:72-84.

75. Rai V (2016) Evaluation of the MTHFR C677T polymorphism as a risk factor for colorectal cancer in Asian populations. Asian Pac J Cancer Prev. 16(18):8093-100.

76. Yadav U, Kumar P, Rai V (2016) Role of MTHFR A1298C gene polymorphism in the etiology of prostate cancer: a systematic review and updated meta-analysis. Egypt J Med Hum Genet 17(2):1418.

77. Kumar P, Rai V (2018) MTHFR C677T polymorphism and risk of esophageal cancer: an updated meta-analysis. Egypt J Med Hum Genet 19: 273-84.

78. Yadav U, Kumar P, Rai V (2018) NQ01 Gene C609T Polymorphism (dbSNP: rs1800566) and Digestive Tract Cancer Risk: A Meta-Analysis. Nutr Cancer. 70(4): 557-68.

79. Lewis SJ, Baker I, Davey Smith G (2005) Meta-analysis of vitamin D receptor polymorphisms and pulmonary tuberculosis risk. Int J Tuberc Lung Dis. 9(10):1174-7.

80. Gao L, Tao Y, Zhang L, Jin Q (2010) Vitamin D receptor genetic polymorphisms and tuberculosis: updated systematic review and meta-analysis. Int J Tuberc Lung Dis. 14(1):15-23.

81. Chen C, Liu Q, Zhu L, Yang H, Lu W (2013) Vitamin D receptor gene polymorphisms on the risk of tuberculosis, a meta-analysis of 29 case-control studies. PLoS One. 8(12):e83843.

82. Sun YP, Cai QS (2015) Vitamin D receptor Fokl gene polymorphism and tuberculosis susceptibility: a meta-analysis. Genet Mol Res. 14(2):6156-63.

83. Huang L, Liu C, Liao G, Yang X, Tang X, Chen J (2015) Vitamin D Receptor Gene Fokl Polymorphism Contributes to Increasing the Risk of Tuberculosis: An Update Meta-Analysis. Medicine (Baltimore). 94(51):e2256.

84. Cao Y, Wang X, Cao Z, Cheng X (2016) Vitamin D receptor gene Fokl polymorphisms and tuberculosis susceptibility: a meta-analysis. Arch Med Sci. 12(5):1118-34.

85. Wang Y, Li HJ (2019) A meta-analysis on associations between vitamin D receptor genetic variants and tuberculosis. Microb Pathog. 130:59-64. 
86. Xu X, Shen M (2019) Associations between vitamin D receptor genetic variants and tuberculosis: a meta-analysis. Innate Immun. 25(5):305-13.

87. Mohammadi A, Khanbabaei H, Nasiri-Kalmarzi R, Khademi F, Jafari M, Tajik N (2020) Vitamin D receptor Apal (rs7975232), Bsml (rs1544410), Fok1 (rs2228570), and Taql (rs731236) gene polymorphisms and susceptibility to pulmonary tuberculosis in an Iranian population: A systematic review and meta-analysis. J Microbiol Immunol Infect. 53(6):827-35.

\section{Table}

Table 1. Summary estimates for the odds ratio (OR) of Fokl in various allele/genotype contrasts, the significance level ( $p$ value) of heterogeneity test ( $Q$ test), and the $I^{2}$ metric: overall analysis, and subgroup analyses. 


\begin{tabular}{|c|c|c|c|c|c|c|}
\hline \multirow[t]{2}{*}{$\begin{array}{l}\text { Genetic } \\
\text { Contrast }\end{array}$} & & \multirow{2}{*}{$\begin{array}{l}\text { Fixed effect } \\
\text { OR ( } 95 \% \\
\text { Cl), p }\end{array}$} & \multirow{2}{*}{$\begin{array}{l}\begin{array}{l}\text { Random } \\
\text { effect }\end{array} \\
\text { OR (95\% } \\
\text { Cl), p }\end{array}$} & \multirow[t]{2}{*}{$\begin{array}{l}\text { Heterogeneity } \\
\text { p-value ( } Q \text { test) }\end{array}$} & \multirow[t]{2}{*}{$\mathrm{I}^{2}(\%)$} & \multirow{2}{*}{$\begin{array}{l}\text { Publication } \\
\text { Bias ( } p \text { of } \\
\text { Eggers test) }\end{array}$} \\
\hline & & & & & & \\
\hline \multirow{5}{*}{$\begin{array}{l}\text { All } \\
\text { (44 } \\
\text { studies) }\end{array}$} & $\begin{array}{l}\text { Allele } \\
\text { Contrast (f } \\
\text { vs. F) }\end{array}$ & $\begin{array}{l}1.16(1.10- \\
1.22) \\
<0.001\end{array}$ & $\begin{array}{l}1.11(0.99- \\
1.24), 0.05\end{array}$ & $<0.001$ & 73.46 & 0.10 \\
\hline & $\begin{array}{l}\text { Dominant } \\
\text { (ff+Ff vs. } \\
\text { FF) }\end{array}$ & $\begin{array}{l}1.14(1.06- \\
1.22) \\
<0.001\end{array}$ & $\begin{array}{l}1.11(0.96- \\
1.28), 0.14\end{array}$ & $<0.001$ & 71.39 & 0.45 \\
\hline & $\begin{array}{l}\text { Homozygote } \\
\text { (ff vs. FF) }\end{array}$ & $\begin{array}{l}1.46(1.29- \\
1.66) \\
<0.001\end{array}$ & $\begin{array}{l}1.32(1.03- \\
1.69), 0.02\end{array}$ & $<0.001$ & 67.02 & 0.22 \\
\hline & $\begin{array}{l}\text { Co- } \\
\text { dominant } \\
\text { (Ff vs. FF) }\end{array}$ & $\begin{array}{l}1.08(1.00- \\
1.17), 0.02\end{array}$ & $\begin{array}{l}1.05(0.92- \\
1.21), 0.41\end{array}$ & $<0.001$ & 65.97 & 0.48 \\
\hline & $\begin{array}{l}\text { Recessive } \\
\text { (FF+Ff vs. } \\
\text { ff) }\end{array}$ & $\begin{array}{l}1.39(1.24- \\
1.55) \\
<0.001\end{array}$ & $\begin{array}{l}1.26(1.03- \\
1.54), 0.02\end{array}$ & $<0.001$ & 58.01 & 0.15 \\
\hline \multirow{5}{*}{$\begin{array}{l}\text { Asian } \\
\text { (29 } \\
\text { studies) }\end{array}$} & $\begin{array}{l}\text { Allele } \\
\text { Contrast (f } \\
\text { vs. F) }\end{array}$ & $\begin{array}{l}1.25(1.16- \\
1.34) \\
<0.001\end{array}$ & $\begin{array}{l}1.15(0.98- \\
1.34), 0.06\end{array}$ & $<0.001$ & 77.48 & 0.75 \\
\hline & $\begin{array}{l}\text { Dominant } \\
\text { (ff+Ff vs. } \\
\text { FF) }\end{array}$ & $\begin{array}{l}1.23(1.12- \\
1.36) \\
<0.001\end{array}$ & $\begin{array}{l}1.15(0.93- \\
1.41), 0.18\end{array}$ & $<0.001$ & 77.47 & 0.65 \\
\hline & $\begin{array}{l}\text { Homozygote } \\
\text { (ff vs. FF) }\end{array}$ & $\begin{array}{l}1.76(1.50- \\
2.07), \\
<0.001\end{array}$ & $\begin{array}{l}1.57(1.12- \\
2.21), \\
0.008\end{array}$ & $<0.001$ & 70.37 & 0.91 \\
\hline & $\begin{array}{l}\text { Co- } \\
\text { dominant } \\
\text { (Ff vs. FF) }\end{array}$ & $\begin{array}{l}1.14(1.03- \\
1.26), 0.008\end{array}$ & $\begin{array}{l}1.06(0.86- \\
1.31), 0.53\end{array}$ & $<0.001$ & 74.73 & 0.32 \\
\hline & $\begin{array}{l}\text { Recessive } \\
\text { (FF+Ff vs. } \\
\text { ff) }\end{array}$ & $\begin{array}{l}1.59(1.37- \\
1.84) \\
<0.001\end{array}$ & $\begin{array}{l}1.43(1.08- \\
1.89), 0.01\end{array}$ & $<0.001$ & 63.13 & 0.68 \\
\hline \multirow[t]{3}{*}{$\begin{array}{l}\text { African } \\
\text { (8 } \\
\text { studies) }\end{array}$} & $\begin{array}{l}\text { Allele } \\
\text { Contrast (f } \\
\text { vs. F) }\end{array}$ & $\begin{array}{l}1.01(0.91- \\
1.12), 0.81\end{array}$ & $\begin{array}{l}1.01(0.91- \\
1.12), 0.81\end{array}$ & 0.76 & 0 & 0.27 \\
\hline & $\begin{array}{l}\text { Dominant } \\
\text { (ff+Ff vs. } \\
\text { FF) }\end{array}$ & $\begin{array}{l}1.02(0.89- \\
1.16), 0.77\end{array}$ & $\begin{array}{l}1.01(0.89- \\
1.16), 0.77\end{array}$ & 0.59 & 0 & 0.07 \\
\hline & Homozygote & 1.01 (0.75- & $\begin{array}{r}1.01(0.75- \\
\text { Page } 14 / 20\end{array}$ & 0.99 & 0 & 0.45 \\
\hline
\end{tabular}




\begin{tabular}{|c|c|c|c|c|c|c|}
\hline & (ff vs. FF) & $1.34), 0.94$ & \multicolumn{4}{|l|}{$1.34), 0.94$} \\
\hline & $\begin{array}{l}\text { Co- } \\
\text { dominant } \\
\text { (Ff vs. FF) }\end{array}$ & $\begin{array}{l}1.02(0.89- \\
1.17), 0.74\end{array}$ & $\begin{array}{l}1.02(0.89- \\
1.17), 0.75\end{array}$ & 0.51 & 0 & 0.06 \\
\hline & $\begin{array}{l}\text { Recessive } \\
\text { (FF+Ff vs. } \\
\text { ff) }\end{array}$ & $\begin{array}{l}0.99(0.75- \\
1.32), 0.97\end{array}$ & $\begin{array}{l}0.99(0.75- \\
1.32), 0.97\end{array}$ & 0.99 & 0 & 0.62 \\
\hline \multirow{5}{*}{$\begin{array}{l}\text { South } \\
\text { American } \\
\text { (6 } 6 \\
\text { studies) }\end{array}$} & $\begin{array}{l}\text { Allele } \\
\text { Contrast (f } \\
\text { vs. F) }\end{array}$ & $\begin{array}{l}1.11(0.97- \\
1.28), 0.12\end{array}$ & $\begin{array}{l}0.99(0.72- \\
1.35), 0.96\end{array}$ & $<0.001$ & 76.22 & 0.66 \\
\hline & $\begin{array}{l}\text { Dominant } \\
\text { (ff+Ff vs. } \\
\text { FF) }\end{array}$ & $\begin{array}{l}1.06(0.86- \\
1.30), 0.57\end{array}$ & $\begin{array}{l}0.95(0.66- \\
1.35), 0.78\end{array}$ & 0.02 & 61.24 & 0.61 \\
\hline & $\begin{array}{l}\text { Homozygote } \\
\text { (ff vs. FF) }\end{array}$ & $\begin{array}{l}1.24(0.92- \\
1.67), 0.14\end{array}$ & $\begin{array}{l}0.87(0.41- \\
1.84), 0.72\end{array}$ & $<0.001$ & 76.41 & 0.35 \\
\hline & $\begin{array}{l}\text { Co- } \\
\text { dominant } \\
\text { (Ff vs. FF) }\end{array}$ & $\begin{array}{l}1.01(0.81- \\
1.26), 0.89\end{array}$ & $\begin{array}{l}0.97(0.74- \\
1.27), 0.84\end{array}$ & 0.24 & 25.68 & 0.77 \\
\hline & $\begin{array}{l}\text { Recessive } \\
\text { (FF+Ff vs. } \\
\text { ff) }\end{array}$ & $\begin{array}{l}1.28(1.00- \\
1.63), 0.04\end{array}$ & $\begin{array}{l}1.02(0.61- \\
1.72), 0.92\end{array}$ & 0.008 & 67.96 & 0.28 \\
\hline
\end{tabular}

Figures 
Wilkinson et al., 2000

Selvaraj et al., 2003

Liu et al., 2004

Selvaraj et al., 2004a

Selvaraj et al., 2004b

Selvaraj et al., 2008

Alagarasu et al., 2009

Merza et al., 2009

Selvaraj et al., 2009

Vidyarani et al., 2009

Banoei et al., 2010

Marashian et al., 2010

Zhang et al., 2010

Kang et al., 2011

Sharma et al., 2011

Singh et al., 2011

Rathored et al., 2012

Joshi et al., 2014

Rashedi et al., 2014

Sinaga et al., 2014

Salimi et al., 2015

Wu et al., 2015

Jafari et al., 2016

Lee et al., 2016

Medapati et al., 2017

Wang et al., 2017

Devi et al., 2018

Zhang et al., 2018

Panda et al., 2019

Subgroup Asian (1^2=77.48 \% , P=0.000)

Bornman et al., 2004

Lombard et al., 2006

Babb et al., 2007

Olesen et al., 2007

Søborg et al., 2007

Arji et al., 2014

Mahmoud and Ali, 2014

Acen et al., 2016

Subgroup African $\left(\left.\right|^{\wedge} 2=0 \%, P=0.760\right)$

Roth et al., 2004

Wilbur et al., 2007

Fernández-Mestre et al., 2015

Silva-Ramirez et al., 2019

Silva et al., 2020

de Albuquerque Borborema et al., 2020

Subgroup South American $\left(I^{\wedge} 2=76.22 \%, P=0.001\right)$

Ates et al., 2011

Subgroup Europen ( $\left(^{\wedge} 2=N A, P=N A\right)$

Overall $\left(I^{\wedge} 2=73.46 \%, P=0.000\right)$
$1.447(0.909,2.303)$

$0.639(0.400,1.020)$

$1.501(1.099,2.051)$

$0.456(0.256,0.810)$

$1.010(0.533,1.913)$

$0.811(0.442,1.490)$

$0.955(0.663,1.377)$

$1.140(0.667,1.947)$

$1.211(0.682,2.148)$

$0.793(0.407,1.545)$

$1.049(0.613,1.797)$

$0.460(0.286,0.740)$

$0.577(0.409,0.813)$

$1.097(0.743,1.620)$

$1.733(1.390,2.159)$

$0.707(0.488,1.026)$

$1.609(1.245,2.079)$

$1.290(0.861,1.932)$

$1.068(0.666,1.712)$

$0.945(0.594,1.504)$

$1.829(1.192,2.807)$

$1.487(1.134,1.950)$

$1.065(0.707,1.605)$

$1.330(0.994,1.779)$

$1.123(0.735,1.714)$

$2.010(1.443,2.801)$

$1.325(0.977,1.797)$

$2.563(1.676,3.919)$

$2.276(1.611,3.213)$

$1.153(0.989,1.345)$

$1.005(0.816,1.238)$

$1.593(0.853,2.974)$

$1.118(0.859,1.457)$

$0.937(0.723,1.215)$

$0.918(0.723,1.166)$

$0.999(0.746,1.338)$

$1.227(0.599,2.514)$

$1.437(0.437,4.729)$

$1.013(0.910,1.128)$

$1.080(0.735,1.587)$

$0.990(0.547,1.791)$

$0.752(0.502,1.126)$

$1.581(1.272,1.966)$

$1.010(0.683,1.494)$

$0.674(0.465,0.978)$

$0.993(0.728,1.353)$

$0.918(0.602,1.400)$

$0.918(0.602,1.400)$

$1.113(0.997,1.243)$
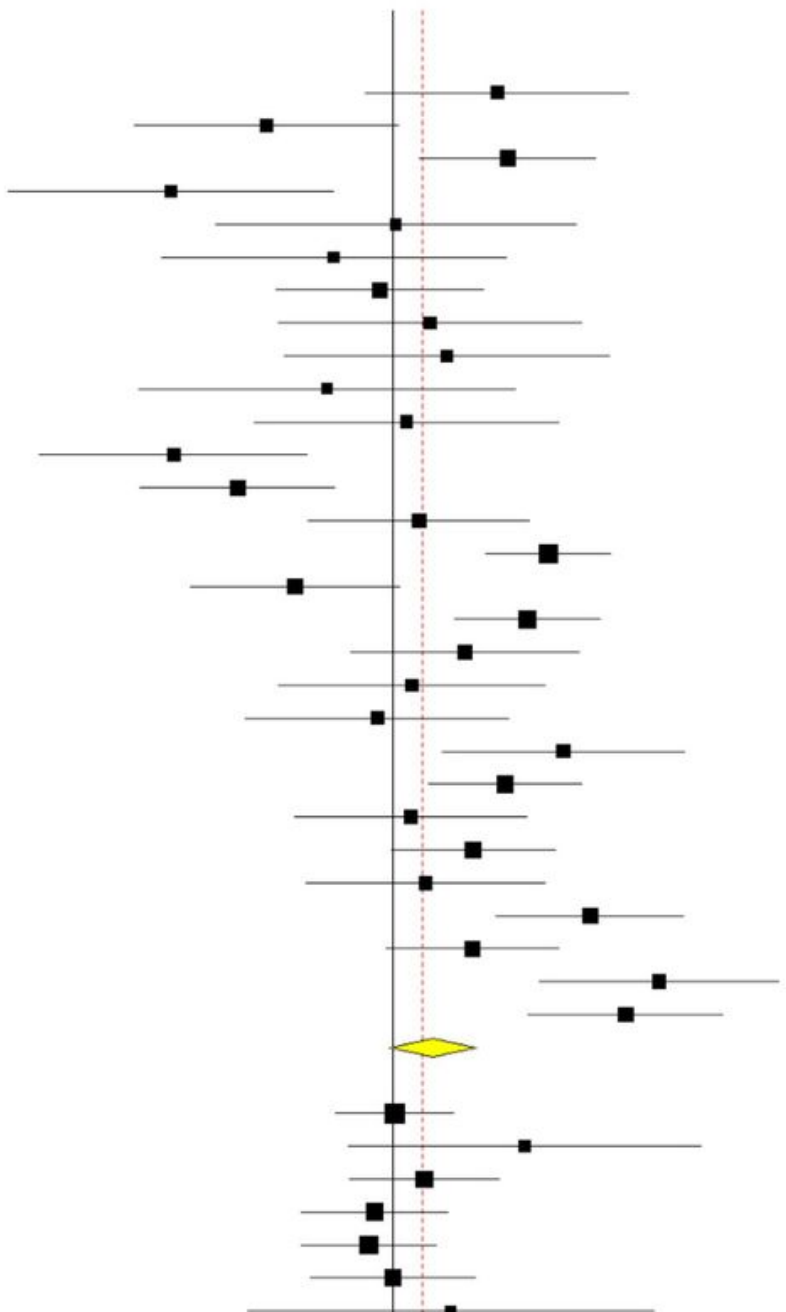

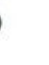

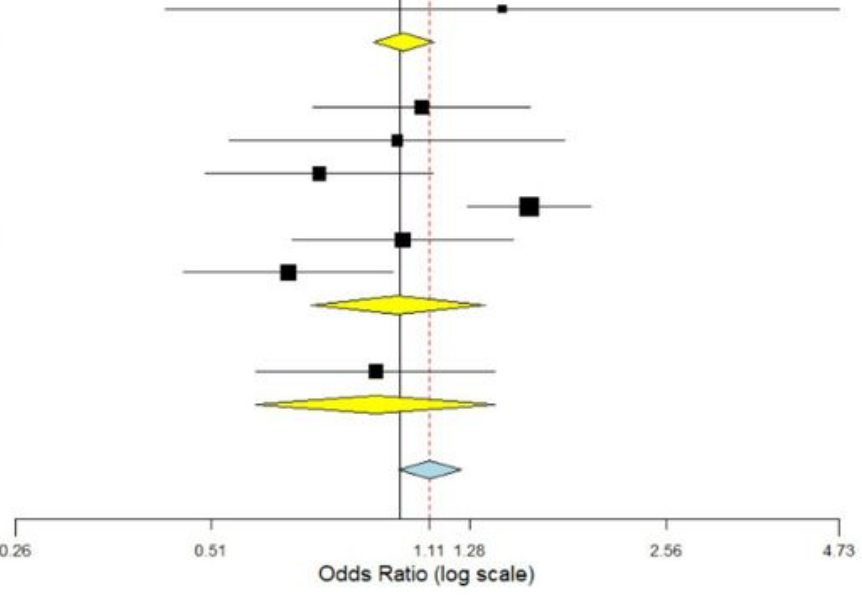

\section{Figure 1}

Random effect forest plot of allele contrast model of VDR Fokl polymorphism. Results of individual and summary OR estimates, and $95 \% \mathrm{Cl}$ of each study were shown. Horizontal lines represented $95 \% \mathrm{Cl}$, and dotted vertical lines represent the value of the summary OR. 
Studies

Wilkinson et al., 2000

Selvaraj et al., 2003

Liu et al., 2004

Selvaraj et al., 2004a

Selvaraj et al., 2004b

Selvaraj et al., 2008

Alagarasu et al., 2009

Merza et al., 2009

Selvaraj et al., 2009

Vidyarani et al., 2009

Banoei et al., 2010

Marashian et al., 2010

Zhang et al., 2010

Kang et al., 2011

Sharma et al., 2011

Singh et al., 2011

Rathored et al., 2012

Joshi et al., 2014

Rashedi et al., 2014

Sinaga et al., 2014

Salimi et al., 2015

Wu et al., 2015

Jafari et al., 2016

Lee et al., 2016

Medapati et al., 2017

Wang et al., 2017

Devi et al., 2018

Zhang et al., 2018

Panda et al., 2019

Subgroup Asian ( $\left(^{\wedge} 2=77.47 \%, P=0.000\right)$

Bornman et al., 2004

Lombard et al., 2006

Babb et al., 2007

Olesen et al., 2007

Søborg et al., 2007

Arji et al., 2014

Mahmoud and Ali, 2014

Acen et al., 2016

Subgroup African $\left(\left.\right|^{\wedge} 2=0 \%, P=0.592\right)$

Roth et al., 2004

Wilbur et al., 2007

Fernández-Mestre et al., 2015

Silva-Ramirez et al., 2019

Silva et al., 2020

de Albuquerque Borborema et al., 2020

Ates et al., 2011

Subgroup Europen $\left(1^{\wedge} 2=N A, P=N A\right)$

Overall $\left(I^{\wedge} 2=71.39 \%, P=0.000\right)$
Estimate (95\% C.I.)

$1.321(0.753,2.318)$

$0.626(0.351,1.115)$

$1.721(1.049,2.822)$

$0.414(0.211,0.815)$

$0.940(0.433,2.038)$

$0.528(0.247,1.127)$

$0.787(0.506,1.225)$

$1.045(0.556,1.963)$

$1.185(0.586,2.395)$

$0.510(0.219,1.189)$

$0.879(0.432,1.789)$

$0.296(0.150,0.584)$

$0.332(0.196,0.562)$

$1.559(0.874,2.779$

$1.622(1.228,2.143)$

$0.622(0.388,0.998)$

$1.586(1.158,2.173)$

$1.402(0.829,2.369)$

$1.136(0.626,2.064)$

$1.184(0.613,2.284)$

$2.071(1.230,3.486)$

$1.642(1.126,2.394)$

$1.101(0.642,1.888)$

$1.500(0.939,2.397)$

$2.839(0.955,8.446)$

$2.063(1.153,3.689)$

$2.054(1.364,3.095)$

$4.184(2.076,8.433)$

$2.321(1.460,3.690)$

$1.150(0.933,1.418)$

$0.992(0.774,1.273)$

$1.765(0.866,3.597)$

$1.208(0.871,1.674)$

$0.931(0.681,1.272)$

$0.915(0.690,1.213)$

$0.945(0.656,1.360)$

$1.556(0.546,4.435)$

$1.759(0.392,7.902)$

$1.019(0.895,1.161)$

$0.762(0.318,1.823)$

$1.023(0.523,1.998)$

$0.594(0.321,1.096)$

$1.678(1.189,2.368)$

$0.947(0.555,1.615)$

$0.772(0.492,1.211$

$0.939(0.535,1.647)$

$0.939(0.535,1.647)$

$1.112(0.964,1.282)$
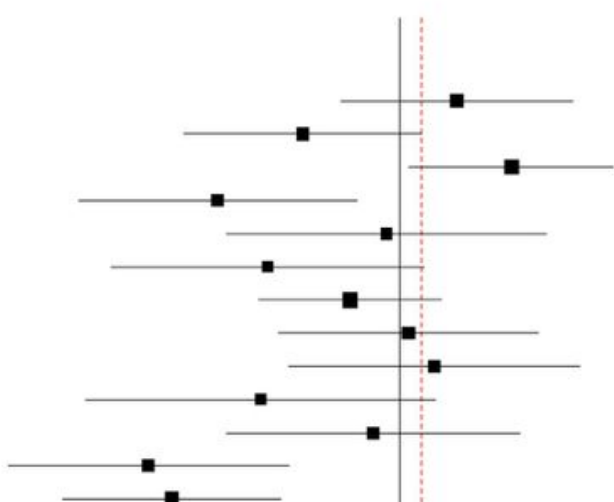

-
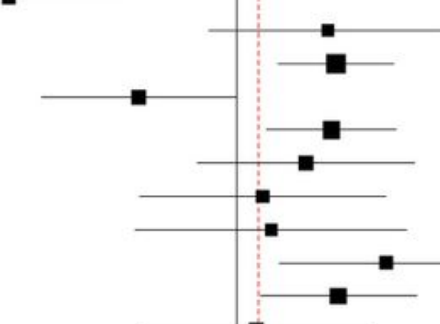

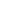

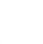

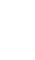

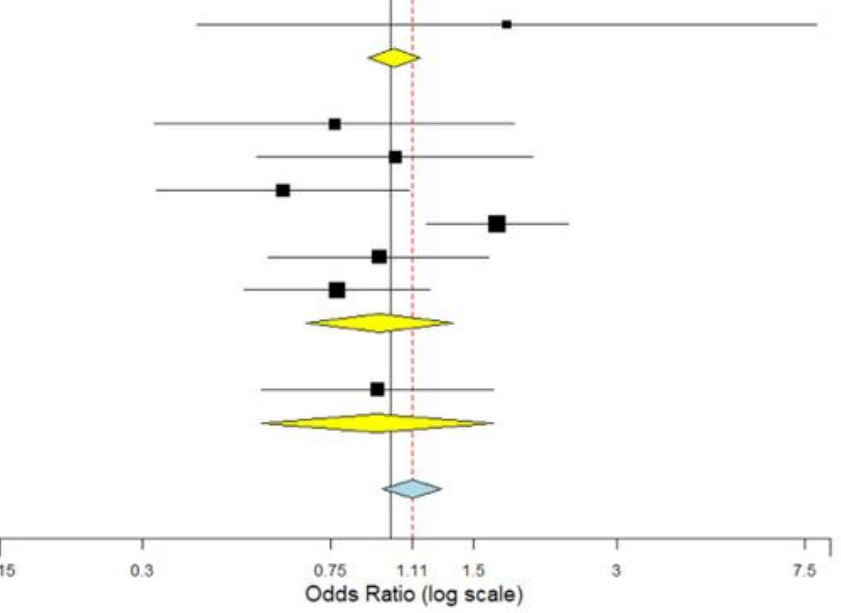

\section{Figure 2}

Random effect forest plot of dominant model of VDR Fokl polymorphism. 
Studies

Wilkinson et al., 2000

Selvaraj et al., 2003

Liu et al., 2004

Selvaraj et al., 2004a

Selvaraj et al., 2004b

Selvaraj et al., 2008

Alagarasu et al., 2009

Merza et al., 2009

Selvaraj et al., 2009

Vidyarani et al., 2009

Banoei et al., 2010

Marashian et al., 2010

Zhang et al., 2010

Kang et al., 2011

Sharma et al., 2011

Singh et al., 2011

Rathored et al., 2012

Joshi et al., 2014

Rashedi et al., 2014

Sinaga et al., 2014

Salimi et al., 2015

Wu et al., 2015

Jafari et al., 2016

Lee et al., 2016

Medapati et al., 2017

Wang et al., 2017

Devi et al., 2018

Zhang et al., 2018

Panda et al., 2019

Subgroup Asian $\left(I^{\wedge} 2=70.37 \%, P=0.000\right)$

Bornman et al., 2004

Lombard et al., 2006

Babb et al., 2007

Olesen et al., 2007

Søborg et al., 2007

Arji et al., 2014

Mahmoud and Ali, 2014

Acen et al., 2016

Subgroup African ( $\left.\left.\right|^{\wedge} 2=0 \%, P=0.994\right)$

Roth et al., 2004

Wilbur et al., 2007

Fernández-Mestre et al., 2015

Silva-Ramirez et al., 2019

Silva et al., 2020

de Albuquerque Borborema et al., 2020

Subgroup South American $\left(I^{\wedge} 2=76.41 \%, P=0.001\right)$

Ates et al., 2011

Subgroup Europen $\left(1^{\wedge} 2=N A, P=N A\right)$

Overall $\left(I^{\wedge} 2=67.02 \%, P=0.000\right)$
Estimate (95\% C.I.)

$3.795(0.961,14.986)$

$0.413(0.135,1.270)$

$2.345(1.222, \quad 4.499)$

$0.260(0.054,1.264)$

$1.357(0.255,7.232)$

$7.857(0.405,152.567)$

$2.269(0.714,7.211)$

$4.733(0.248,90.423)$

$3.000(0.297, \quad 30.345)$

$6.106(0.297,125.354)$

$1.450(0.458,4.590)$

$0.309(0.093,1.030)$

$0.471(0.251, \quad 0.884)$

$0.976(0.433,2.201)$

$4.713(2.723,8.155)$

$0.551(0.208,1.463)$

$3.963(1.776,8.846)$

$1.460(0.603, \quad 3.533)$

$0.994(0.334,2.964)$

$0.648(0.223,1.885)$

$2.248(0.828,6.107)$

$2.069(1.167,3.668)$

$1.118(0.319, \quad 3.917)$

$1.811(0.994, \quad 3.299)$

$1.920(0.475, \quad 7.766)$

$3.166(1.661,6.032)$

$0.448(0.145,1.384)$

$6.077(2.617,14.113)$

4.450 (2.173, 9.114)

$1.578(1.126,2.212)$

$1.076(0.603,1.920)$

$1.535(0.208,11.310)$

$1.000(0.481,2.078)$

$0.880(0.440,1.760)$

$0.839(0.441,1.595)$

$1.203(0.564,2.565)$

$1.333(0.330,5.393)$

$1.056(0.141,7.896)$

$1.010(0.757,1.346)$

$0.847(0.347,2.071)$

$0.765(0.030,19.245)$

$0.574(0.232,1.419)$

$2.436(1.585,3.744)$

$1.095(0.492,2.437)$

$0.284(0.103,0.781)$

$0.872(0.412,1.846)$

$0.754(0.272, \quad 2.092)$

$0.754(0.272, \quad 2.092)$

$1.326(1.035,1.699)$

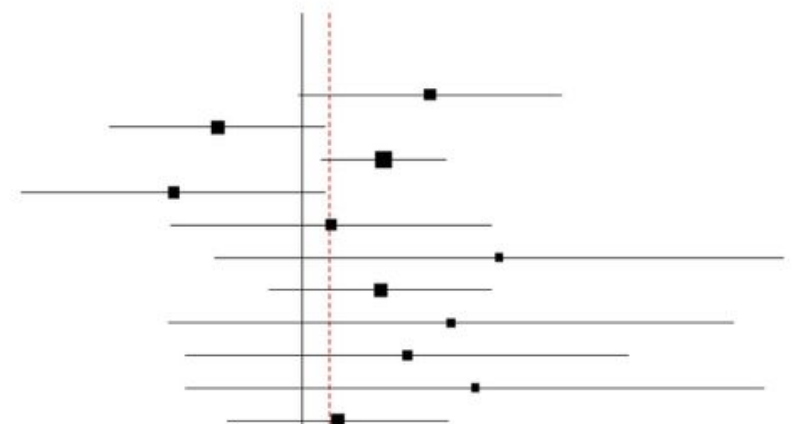

$\longrightarrow$

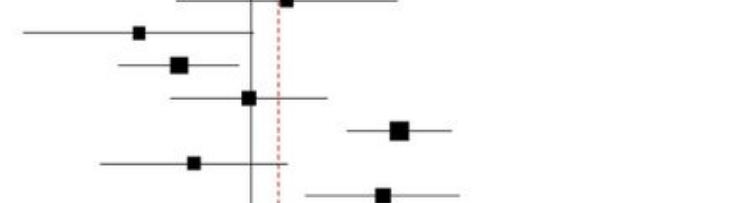

)

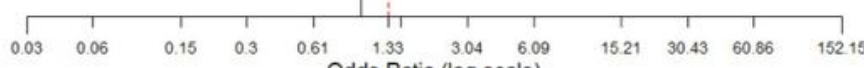

Odds Ratio (log scale)

\section{Figure 3}

Random effect forest plot of homozygote model of VDR Fokl polymorphism. 
Studies

Wilkinson et al., 2000

Selvaraj et al., 2003

Liu et al., 2004

Selvaraj et al., 2004a

Selvaraj et al., 2004b

Selvaraj et al., 2008

Alagarasu et al., 2009

Merza et al., 2009

Selvaraj et al., 2009

Vidyarani et al., 2009

Banoei et al., 2010

Marashian et al., 2010

Zhang et al., 2010

Kang et al., 2011

Sharma et al., 2011

Singh et al., 2011

Rathored et al., 2012

Joshi et al., 2014

Rashedi et al., 2014

Sinaga et al., 2014

Salimi et al., 2015

Wu et al., 2015

Jafari et al., 2016

Lee et al., 2016

Medapati et al., 2017

Wang et al., 2017

Devi et al., 2018

Zhang et al., 2018

Panda et al., 2019

Subgroup Asian ( $\left(^{\wedge} 2=63.13 \%, P=0.000\right)$

Bornman et al., 2004

Lombard et al., 2006

Babb et al., 2007

Olesen et al., 2007

Søborg et al., 2007

Arji et al., 2014

Mahmoud and Ali, 2014

Acen et al., 2016

Subgroup African $\left(I^{\wedge} 2=0 \%, P=0.997\right)$

Roth et al., 2004

Wilbur et al., 2007

Fernández-Mestre et al., 2015

Silva-Ramírez et al., 2019

Silva et al., 2020

de Albuquerque Borborema et al., 2020

Subgroup South American $\left(I^{\wedge} 2=67.96 \%, P=0.008\right)$

Ates et al., 2011

Subgroup Europen (I^2=NA , P=NA)

Overall $\left(\left.\right|^{\wedge} 2=58.01 \%, P=0.000\right)$
Estimate (95용 C.I.)

$3.631(0.935,14.100)$

$0.474(0.158,1.421)$

$1.783(1.024,3.104)$

$0.337(0.070,1.612)$

$1.419(0.273,7.366)$

$11.463(0.602,218.215)$

$2.615(0.834,8.197)$

$4.797(0.254,90.597)$

$2.855(0.289,28.222)$

$9.240(0.463,184.372)$

$1.647(0.548,4.950)$

$0.584(0.190,1.798)$

$0.917(0.536,1.568)$

$0.682(0.330,1.410)$

$4.211(2.466,7.190)$

$0.685(0.265,1.770)$

$3.438(1.559, \quad 7.583)$

$1.267(0.542, \quad 2.962)$

$0.932(0.323, \quad 2.692)$

$0.541(0.201,1.459)$

$1.788(0.670,4.772)$

$1.672(0.982, \quad 2.847)$

$1.062(0.314,3.591)$

$1.457(0.883,2.404)$

$0.721(0.270,1.925)$

2.548 (1.577, 4.115)

$0.281(0.093,0.848)$

$2.768(1.399,5.476)$

$3.451(1.750,6.806)$

1.435 (1.088, 1.894)

$1.083(0.611, \quad 1.919)$

$1.313(0.180,9.571)$

$0.914(0.446,1.875)$

$0.900(0.455, \quad 1.783)$

$0.859(0.455,1.622)$

$1.253(0.598,2.626)$

$1.000(0.287, \quad 3.488)$

$1.000(0.134,7.460)$

$0.996(0.751,1.320)$

$1.219(0.755$,

$0.755(0.030$,

$0.796(0.355$,

$1.979(1.380$,

$1.154(0.546$,

$0.289(0.107$,

$1.026(0.610$,

1.968)

18.838)

$1.786)$

2.838)

2. 440)

$0.783)$

1.725)

$0.763(0.288, \quad 2.022)$

$0.763(0.288, \quad 2.022)$

$1.264(1.036,1.544)$
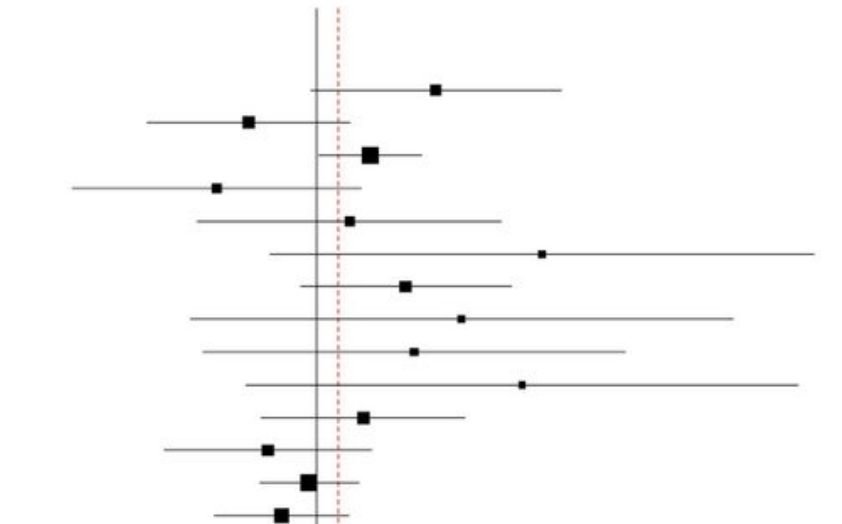

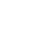

.

.

.

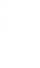

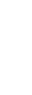

)


a
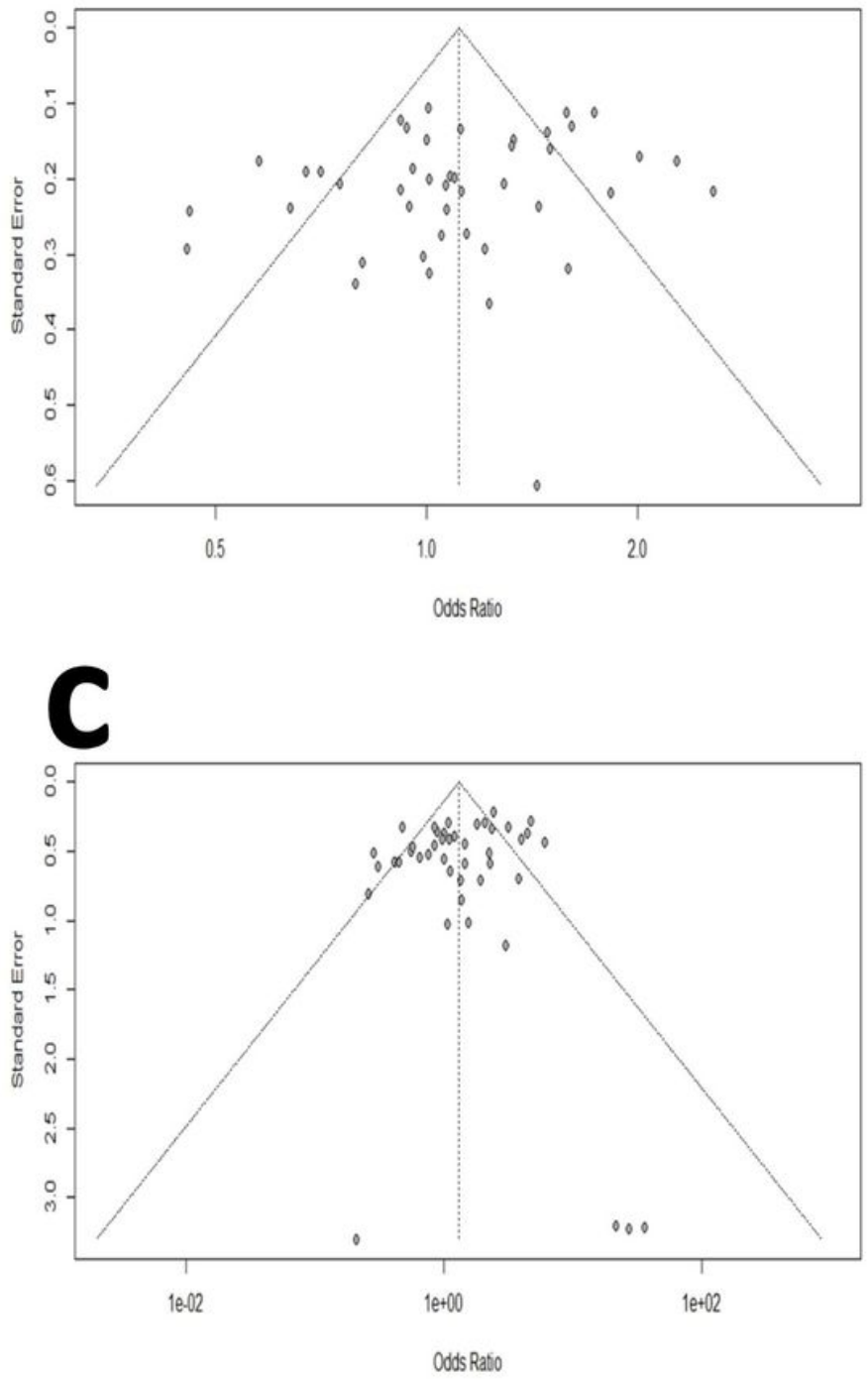
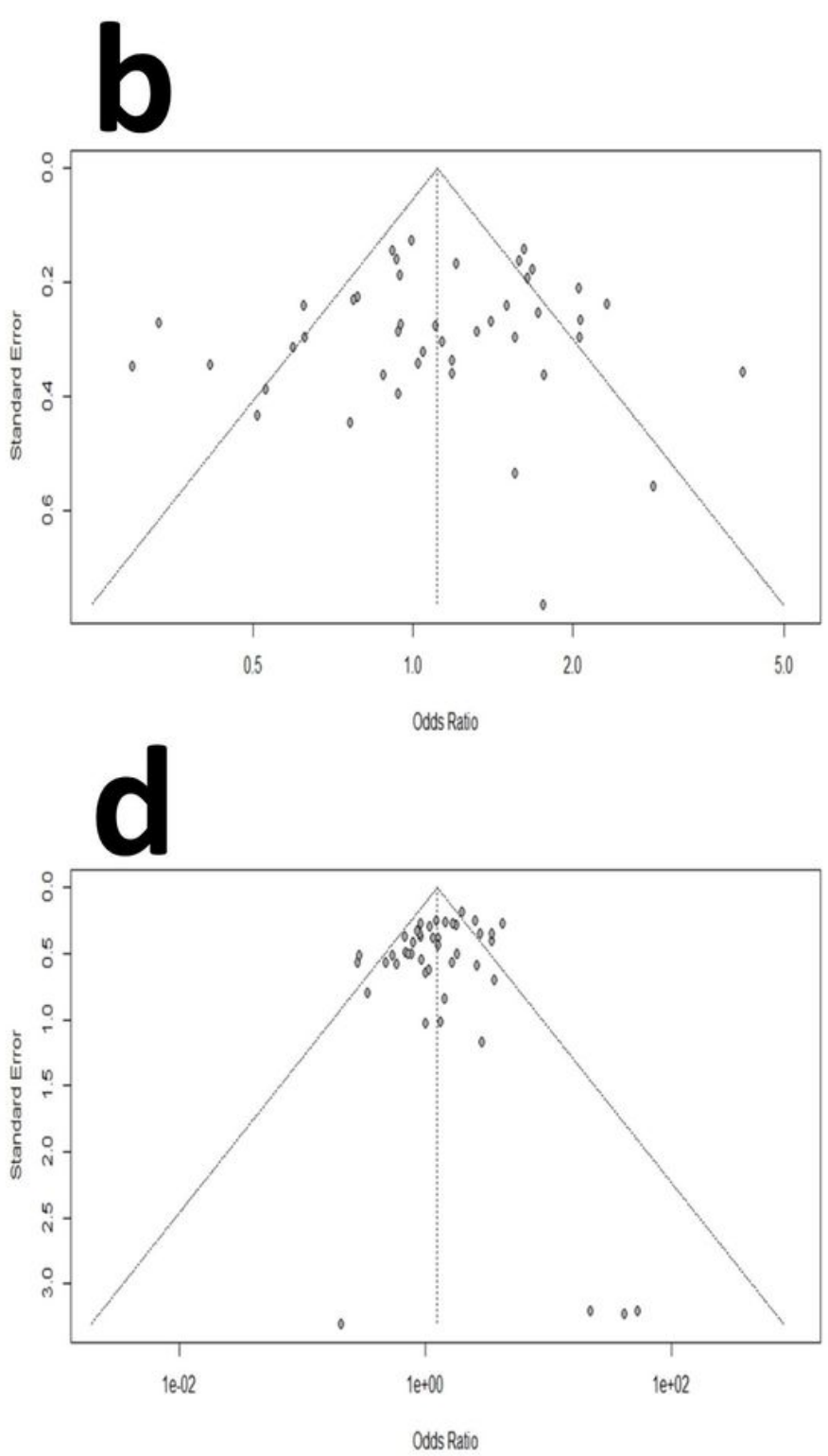

Figure 5

Funnel plots of standard error by log odds ratio for a) allele contrast model; b) dominant model; c) homozygote model; and d) recessive model. 